\title{
Comparison between Induction of Labor and Expectant Management in Post-Date Pregnancy
}

\author{
MOHAMMED A. MOHAMMED, M.Sc.*; FARID I. HASSAN, M.D.*; WAEL S. TAHA, M.D.* and \\ RAGHDAA M. ALI, M.D.** \\ The Department of Obstetrics and Gynecology, Faculty of Medicine, Al-Azhar University* and \\ The Department of Neonatology, Ahmed Maher Teaching Hospital, GOTHI**
}

\begin{abstract}
Background: Post-date pregnancy is associated with increased perinatal morbidity and mortality. Therefore postdate pregnancy is considered as a high-risk condition which requires specialist surveillance and induction of labor at some stage. The aim of this work is to evaluate if a policy of induction of labor at $41 \mathrm{GW}$ is superior, in terms of neonatal and maternal outcomes, as compared to expectant management in healthy women with a low risk singleton pregnancy.
\end{abstract}

Aim of Study: The aim with this study is to evaluate if a policy of induction of labor at $41 \mathrm{GW}$ is superior, in terms of neonatal and maternal outcomes, as compared to expectant management in healthy women with a low risk singleton pregnancy.

Patients and Methods: A prospective case control study A total number of 100 pregnant women will be included in the study divided into 2 groups: Group (1): Consists of 50 pregnant women who undergo induction of labor at $41+0$ or $41+1$ weeks. Group (2): Consists of 50 women who undergo expectant management await spontaneous onset of labor until 42 weeks.

Results: This study shows that Meconium Aspiration Syndrome (MAS) was significantly associated with expectant group as $14 \%$ of this group had it in their children while only $2 \%$ in the induction group, also shows that there are no significant difference between the two groups regarding other perinatal outcomes also shows that rate of CS was significantly associated with induction group $34 \%$ while the rate of CS in expectant group only $16 \%$, also the rate of using analgesia was significantly associated with induction group $44 \%$ while only $22 \%$ in expectant group.

Conclusion: Labor induction at 41 completed weeks should be offered to low risk women. The message from this review is that such a policy is associated with fewer deaths although the absolute risk is small. However, this policy may increase the rate of CS or need of analgesia.

Key Words: Post-date pregnancy - Induction of labor-Postterm pregnancy.

Correspondence to: Dr. Mohammed A. Mohammed, The Department of Obstetrics and Gynecology, Faculty of Medicine, Al-Azhar University

\section{Introduction}

ACCORDING to World Health Organization (WHO), post-date or post-term pregnancy is defined as pregnancy duration of 294 days or longer i.e. Gestational Week (GW) 42 and 0 days $(42+0)$ or more measured from the first day of the last menstrual period.

Post-date pregnancy is associated with increased perinatal morbidity and mortality [1]. Therefore post-date pregnancy is considered as a high-risk condition which requires specialist surveillance and induction of labor at some stage.

The etiology of post-date birth is largely unknown. Some rare, known causes of post-date birth are fetal anencephaly, fetal adrenal hypoplasia or insufficiency and placental sulphatase deficiency. Risk factors for post term birth include: Primiparity, advanced maternal age, maternal obesity, heredity, previous post term pregnancy, and a male fetus [2]

Perinatal Mortality (PNM) is defined as the prevalence of stillbirth (after GW $28+0$ ) and neonatal mortality within 7 days after birth [3] PNM increased in women with post-date pregnancies as compared to women with term pregnancies [4].

The risk of perinatal complications such as Meconium Aspiration Syndrome (MAS), umbilical cord complications, asphyxia, pneumonia, sepsis, convulsions, shoulder dystocia, traumatic injuries and peripheral nerve damage is higher in post-date deliveries than in deliveries at term [4]. Also a higher risk of neonatal encephalopathy in children born post-date [5] 
Maternal complications increase from GW 40. The risk of puerperal infections, postpartum bleeding, disproportion, labor dystocia, emergency caesarean sections, and cervical lacerations was higher for post-date than for term pregnancies [4].

\section{Patients and Methods}

The study is performed at Ahmed Maher Teaching Hospital during the period between September 2016 and October 2017. A total number of 100 pregnant women will be included in the study divided into 2 groups:

- Group (1): Consists of 50 pregnant women who undergo induction of labor at $41+0$ or $41+1$ weeks women with a cervix that is judged to be 'ripe' at vaginal examination (Bishop score of 6 or more), will have labor induced with amniotomy followed by intravenous oxytocin. In case of unripe cervix, cervical ripening will be accomplished by vaginal dinoprostone.

- Group (2): Consists of 50 women who undergo expectant management await spontaneous onset of labor until 42 weeks. Monitoring can consist of consultations, electronic fetal heart rate monitoring and ultrasound assessment of amniotic fluid.

\section{Outcome measures:}

Primary outcome will be a composite of perinatal mortality and neonatal morbidity (meconium aspiration syndrome, birth trauma, and perinatal asphyxia and/or NICU admission).

Secondary outcomes will be maternal outcomes such as operative delivery (operative vaginal delivery, caesarean section), need for analgesia (epidural, remifentanil, pethidin), postpartum hemorrhage and severe perineal injury (third-or fourthdegree perineal tear).

\section{Inclusion criteria:}

Obstetrical low risk women $\geq 18$ years with singleton pregnancy in stable cephalic position. Gestational age of $40+5-41+0$ without contraindications for expectant management until 42 weeks.

\section{Exclusion criteria:}

Age $<18$ years, uncertain gestational age, high risk pregnancy (e.g. hypertension, proteinuria $(\geq 3$ $\mathrm{g} / \mathrm{L}$ ), pre-existent maternal heart or kidney diseases, gestational diabetes, previous caesarean section, multiple pregnancy, intra-uterine growth retardation and non-reassuring fetal status (no fetal movements, abnormal fetal heart rate, known fetal abnormalities which could influence perinatal outcome, including abnormal karyotype, ruptured membranes at time of randomization and a non-reassuring fetal status at time of randomization).

\section{Results}

Table (1): Demographic data of the studied cases.

\begin{tabular}{cl}
\hline & No. $=100$ \\
\hline Age: & \\
Mean $\pm \mathrm{SD}$ & $26.34 \pm 6.82$ \\
Range & $18-42$ \\
$<35$ years & $82(82 \%)$ \\
$>35$ years & $18(18 \%)$ \\
BMI: & \\
Mean $\pm \mathrm{SD}$ & $23.70 \pm 3.32$ \\
Range & $19-32$ \\
$<25$ & $61(61 \%)$ \\
$>25$ & $39(39 \%)$ \\
Parity: & \\
Primigravida & $49(49 \%)$ \\
Multigravida & $51(51 \%)$ \\
History of past date pregnancy & \\
among multigravida: & \\
No & $21(41.2 \%)$ \\
Yes & $30(58.8 \%)$ \\
\hline
\end{tabular}

Table (2): Maternal demographics comparing spontaneous and induction of labor for women delivering at 41 to $41+6$ weeks.

\begin{tabular}{|c|c|c|c|c|c|}
\hline & $\begin{array}{c}\text { Expectant } \\
\text { No. }=50\end{array}$ & $\begin{array}{c}\text { Induction } \\
\text { No. }=50\end{array}$ & $\begin{array}{c}\text { Test } \\
\text { value }\end{array}$ & $\begin{array}{c}p- \\
\text { value }\end{array}$ & Sig. \\
\hline \multicolumn{6}{|l|}{ Age: } \\
\hline Mean $\pm S D$ & $27.74 \pm 7.14$ & $24.94 \pm 6.24$ & $2.087 \bullet$ & 0.039 & $\mathrm{~S}$ \\
\hline Range & $18-42$ & $18-39$ & & & \\
\hline$<35$ years & $38(76 \%)$ & $44(88 \%)$ & $2.439 *$ & 0.118 & NS \\
\hline$>35$ years & $12(24 \%)$ & $6 \quad(12 \%)$ & & & \\
\hline \multicolumn{6}{|l|}{ BMI: } \\
\hline Mean $\pm S D$ & $24.26 \pm 3.31$ & $23.14 \pm 3.27$ & $1.703 \bullet$ & 0.092 & NS \\
\hline Range & $19-30$ & $19-32$ & & & \\
\hline$<25^{\circ}$ & $26(52 \%)$ & $35(70 \%)$ & $3.405^{*}$ & 0.065 & NS \\
\hline$>25$ & $24(48 \%)$ & $15(30 \%)$ & & & \\
\hline \multicolumn{6}{|l|}{ Parity: } \\
\hline Primi gravida & $18(36 \%)$ & $31(62 \%)$ & $6.763 *$ & 0.009 & HS \\
\hline Multiparous & $32(64 \%)$ & $19(38 \%)$ & & & \\
\hline \multirow{4}{*}{\multicolumn{6}{|c|}{$\begin{array}{l}\text { History of past } \\
\text { date pregnancy } \\
\text { among } \\
\text { multigravida: }\end{array}$}} \\
\hline & & & & & \\
\hline & & & & & \\
\hline & & & & & \\
\hline No & $14(43.8 \%)$ & $7 \quad(36.8 \%)$ & $0.235^{*}$ & 0.628 & NS \\
\hline Yes & $18(56.2 \%)$ & $12(63.2 \%)$ & & & \\
\hline
\end{tabular}

This table shows that there was no significant difference between groups regard BMI and the history of post-date pregnancy among multiparous women, expectant group was significantly higher than induction group regard age as they were 27.74 \pm 7.14 and $24.94 \pm 6.24$ respectively and regard parity as multiparous significantly high in expectant group. 
Table (3): Neonatal outcomes comparing expectant management and induction of labor for women delivering at 41 to $41+6$ weeks.

\begin{tabular}{|c|c|c|c|c|c|c|c|}
\hline & \multicolumn{2}{|c|}{ Expectant } & \multicolumn{2}{|c|}{ Induction } & \multirow{2}{*}{$\begin{array}{c}\text { Test } \\
\text { value* }\end{array}$} & \multirow{2}{*}{$\begin{array}{c}p- \\
\text { value }\end{array}$} & \multirow{2}{*}{ Sig. } \\
\hline & No. & $\%$ & No. & $\%$ & & & \\
\hline \multicolumn{8}{|c|}{ Perinatal mortality: } \\
\hline No & 49 & 98 & 50 & 100 & 1.010 & 0.315 & NS \\
\hline Yes & 1 & 2 & 0 & 0 & & & \\
\hline \multicolumn{8}{|l|}{ MAS: } \\
\hline No & 43 & 86 & 49 & 98 & 4.891 & 0.027 & $S$ \\
\hline Yes & 7 & 14 & 1 & 2 & & & \\
\hline \multicolumn{8}{|c|}{ Birth trauma: } \\
\hline No & 49 & 98 & 50 & 100 & 1.010 & 0.315 & NS \\
\hline Yes & 1 & 2 & 0 & 0 & & & \\
\hline \multicolumn{8}{|c|}{ Perinatal asphyxia: } \\
\hline No & 49 & 98 & 48 & 96 & 0.344 & 0.558 & NS \\
\hline Yes & 1 & 2 & 2 & 4 & & & \\
\hline \multicolumn{8}{|c|}{ NICU admission: } \\
\hline No & 43 & 86 & 46 & 92 & 0.919 & 0.338 & NS \\
\hline Yes & 7 & 14 & 4 & 8 & & & \\
\hline
\end{tabular}

This table shows that MAS was significantly associated with expectant group as $14 \%$ of this group had it in their children while only $2 \%$ in the induction group, Also shows that there are no significant difference between the two groups regarding other perinatal outcomes.

Table (4): Maternal outcomes comparing expectant management and induction of labor for women delivering at 41 to $41+6$ weeks.

\begin{tabular}{|c|c|c|c|c|c|c|c|}
\hline & \multicolumn{4}{|c|}{ Expectant Induction } & \multirow{2}{*}{$\begin{array}{c}\text { Test } \\
\text { value* }\end{array}$} & \multirow{2}{*}{$\begin{array}{c}p- \\
\text { value }\end{array}$} & \multirow{2}{*}{ Sig. } \\
\hline & No. & $\%$ & No. & $\%$ & & & \\
\hline \multicolumn{8}{|c|}{ Caesarean section: } \\
\hline No & 42 & 84 & 33 & 66 & 4.320 & 0.038 & S \\
\hline Yes & 8 & 16 & 17 & 34 & & & \\
\hline \multicolumn{8}{|c|}{ Operative vaginal } \\
\hline \multicolumn{8}{|c|}{ delivery: } \\
\hline No & 39 & 7 & 38 & 76 & 0.056 & 0.812 & NS \\
\hline Yes & 11 & 22 & 12 & 24 & & & \\
\hline \multicolumn{8}{|c|}{ Need for analgesia: } \\
\hline No & 39 & 78 & 28 & 56 & 5.473 & 0.019 & S \\
\hline Yes & 11 & 22 & 22 & 44 & & & \\
\hline \multicolumn{8}{|l|}{ PPH: } \\
\hline No & 46 & 92 & 46 & 92 & 0.000 & 1.000 & $\mathrm{NS}$ \\
\hline Yes & 4 & 8 & 4 & 8 & & & \\
\hline \multicolumn{8}{|c|}{ Severe perineal injury: } \\
\hline No & 49 & 98 & 49 & 98 & 0.000 & 1.000 & NS \\
\hline Yes & 1 & 2 & 1 & 2 & & & \\
\hline
\end{tabular}

This table shows that rate of CS was significantly associated with induction group $34 \%$ while the rate of CS in expectant group only $16 \%$, also the rate of using analgesia was significantly associated with induction group $44 \%$ while only $22 \%$ in expectant group.

\section{Discussion}

The main finding in this study is that there is no significant difference in perinatal mortality between induction of labor at 41 weeks' gestation or later as compared to expectant management (test value $1.010, p$-value 0.315 ), there was only one perinatal death in this study 2ry to asphyxia in the expectant group. This results is in keeping with results obtained from Mahomed et al., [6] who reported that there is no significant difference between the two groups regarding stillbirths as the percent of stillbirths in the 2 groups were 0.02 . However in 2016 a paper published in ELSEVIER Sexual \& Reproductive Healthcare journal titled (has perinatal outcome improved after introduction of a guideline in favor of routine induction and increased surveillance prior to 42 weeks of gestation?) Which show that the perinatal mortality rate remained steady in 2009, 2010 and $2011(0.10 \%)$, but was reduced from $60 \%$ from 10 cases in 2010 to three cases in 2012. However, this reduction was not statistically significant $(p=0.10)$ [7].

In this study, we also found that induction of labor compared with expectant management was associated with a significantly lower risk of meconium aspiration syndrome (test value $4.891, p$ value 0.027 ). This results is in keeping with results from Wennerholm et al., who reported that induction of labor was associated with fewer infants with meconium aspiration syndrome compared with expectant management [8]

However, meconium aspiration syndrome is a poor indicator of neonatal stress, and most newborns with meconium aspiration syndrome recover and remain healthy. So There were no significant differences in intensive care unit admissions between induction of labor or expectant management groups (test value $0.919 p$-value 0.338 ). These results are in keeping with results from Burgos et al., [9] and Abraham et al., [10] who reported that no significant difference between the two groups regarding admission of the newborn to NICU.

This study shows no significant difference between the two groups regarding perinatal asphyxia (test value $0.344, p$-value 0.558 ), APGAR score less than 7 at 5 th minute after delivery (test value $-1.158 \#, p$-value 0.247 ) or the rate of birth trauma (test value 1.010, $p$-value 0.315 ) these results are in keeping with results obtained from Gülmezoglu et al., [11] which found that there is no significant difference between the two groups regarding perinatal asphyxia, APGAR score at 5 minute and the 
rate of birth trauma in women who complete 41 weeks and 42 weeks.

The rate of cesarean section in this study is significantly higher in the induction group than the expectant group (test value $4.320, p$-value 0.038 ) these results are similar to results obtained from Thangarajah et al., [12] which found that the rate of the cesarean deliveries was significantly higher in the induction group (33.8\% Vs. $21.1 \%$, $p$-value 0.001$)$. These results also are in keeping with results from Mahomed et al., [6] which found that the incidence of CS was significantly higher in the induction group, $22.2 \%$ versus $12.1 \%$ (OR 2.06; 95\% CI 1.93-2.2). Results from Abraham et al., [10] are also similar to this study results regarding the higher cesarean delivery rate $(p<0.0001)$ when compared to expectant management. However, results obtained from Burgos et al., [13] which compares expectant management and induction at 42 week with induction of labor at 41 week show that the rates of caesarean sections in the two groups were $14.1 \%$ and $11.4 \%$, respectively ( $p=$ $0.01)$.

This study shows significant difference between the two groups regarding the need for analgesia (epidural, remifentanil, pethidin) there were high need for analgesia in the IOL group 44\% compared with $22 \%$ for the expectant group (test value 5.473, $p$-value 0.019). These results are in keeping with results from Mahomed et al., [6] which show significant difference in the epidural use between the IOL and expectant groups (33.5\% versus $21.9 \%)$, but differ from results from Abraham et al., [10] which show no significant difference between the two groups regarding epidural use ( $p$-value 0.55$)$.

The other maternal outcomes in this study show no significant difference between the two groups: Operative vaginal delivery (test value $0.056, p$ value 0.812 ), $\mathrm{PPH}$ (test value $0.000, p$-value 1.000 ) and perineal injury (test value $0.000, p$-value 1.000 ). These results apart from perineal lacerations are in keeping with results from Thangarajah et al., [12] which shows no significant difference between the two groups regarding PPH and operative vaginal delivery but show significantly higher perineal injury in the IOL group $38.1 \%$ compared with $26.4 \%$ in the expectant group ( $p$-value 0.002$)$. Results from Mahomed et al., [6] show no significant difference between the two groups regarding $\mathrm{PPH}$ and $3 \mathrm{rd}$ or $4^{\text {th }}$ degree perineal tear which are similar to this study results. Also, results obtained from Burgos et al., [9] show no significant difference between the two groups regarding instrumental deliveries ( $p$-value 0.69). Sanne et al., [7] found that there was no significant difference between the two groups regarding vacuum extraction ( $p$ value 0.15 ). The results of this study regarding PPH and operative vaginal delivery also similar to results from Gülmezoglu et al., [11] which show no significant difference between the two groups (assisted vaginal delivery $(p=0.65), \mathrm{PPH}(p=0.99))$.

\section{Conclusion:}

Labor induction at 41 completed weeks should be offered to low risk women. The message from this review is that such a policy is associated with fewer deaths although the absolute risk is small. However, this policy may increase the rate of CS or need of analgesia.

There does not seem to be any increased risk of assisted vaginal delivery, perinatal asphyxia, NICU admission, perineal injury or birth trauma.

If the woman chooses to wait for spontaneous labor onset it would be prudent to have regular fetal monitoring as longitudinal epidemiological studies suggest increased risk of perinatal death by increasing gestational age.

\section{References}

1- CHANTRY A.A. and LOPEZ E.: Fetal and neonatal complications related to prolonged pregnancy. J. Gynecol. Obstet. Biol. Reprod (Paris), 40 (8): 717-25, 2011.

2- VAYSSIERE C., HAUMONTE J.B., CHANTRY A., COATLEVEN F., DEBORD M.P., GOMEZ C., Le RAY C., LOPEZ E., SALOMON L.J., SENAT M.V., SENTILHES L., SERRY A., WINER N., GRANDJEAN H., VERSPYCK E. and SUBTIL D.: French College of G., Obstetricians. Prolonged and post-term pregnancies: Guidelines for clinical practice from the French college of gynecologists and obstetricians (CNGOF). Eur. J. Obstet. Gynecol. Reprod. Biol., 169 (1): 10-6, 2013.

3- HUSSAIN A.A., YAKOOB M.Y., IMDAD A. and BHUTTA Z.A.: Elective induction for pregnancies at or beyond 41 weeks of gestation and its impact on stillbirths: A systematic review with meta-analysis. BMC Public Health, 2011.

4- HERMUS M.A., VERHOEVEN C.J., MOL B.W., De Wolf G.S. and FIEDELDEIJ C.A.: Comparison of induction of labour and expectant management in postterm pregnancy: A matched cohort study. J. Midwifery Womens Health, 54 (5): 351-6, 2009.

5- SENAT M.V. : Management of post-term pregnancies: The role for AFI, biophysical score and doppler. J. Gynecol. Obstet. Biol. Reprod, 40 (8): 785-95, 2011.

6- MAHOMED K., PUNGSORNRUK K. and GIBBONS $\mathrm{K}$.: Induction of labour for postdates in nulliparous women with uncomplicated pregnancy-is the caesarean section rate really lower? Journal of Obstetrics and Gynaecology, 14 (59): 1-6, 2016. 
7- SANNE L.W., IBEN L., AGNETE P.K., HEIDI S., MONIQUE M.J. and RIKKE D.M.: Has perinatal outcome improved after introduction of a guideline in favour of routine induction and increased surveillance prior to 42 weeks of gestation? A cross-sectional population-based registry study. Sexual \& Reproductive Healthcare, doi: 10.1016/j. srhc.2016.03.002, 2016.

8- WENNERHOLM U., HAGBERG H., BRORSSON B and BERGH C.: Induction of labor versus expectant management for post-date pregnancy: Is there sufficient evidence for a change in clinical practice? Acta Obstetricia et Gynecologica, 88: 617, 2009.

9- BURGOS J., RODRÍGUEZ L., OTERO B., COBOS P. OSUNA C., DEL MAR CENTENO M., MELCHOR J.C., FERNÁNDEZ-LLEBREZ L. \& MARTÍNEZASTORQUIZA T.: Induction at 41 weeks increases the risk of caesarean section in a hospital with a low rate of caesarean sections. The Journal of Maternal-Fetal and Neonatal Medicine, 25 (9): 1716-8, 2012.

10- ABRAHAM C., SEETHAPPAN V. and DEMISSIE S.: Labor induction with dinoprostone or oxytocin versus expectant management for late-term pregnancies. Clin. Obstet. Gynecol. Reprod Med., 1 (4): 104-7, 2015.

11-GÜLMEZOGLU A.M., CROWTHER C.A. and MIDDLETON P.: Induction of labour for improving birth outcomes for women at or beyond term. Cochrane Database of Systematic Reviews, Issue 4. Art. No.: CD004945. DOI: 10.1002/14651858.CD004945.pub2, 2006.

12- THANGARAJAH F., SCHEUFEN P., KIRN V. and MALLMANN P.: Induction of Labour in Late and Postterm Pregnancies and its Impact on Maternal and Neonatal Outcome. Geburtshilfe und Frauenheilkunde, 76 (07): 793-8, 2016. 


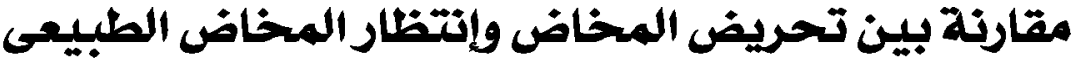

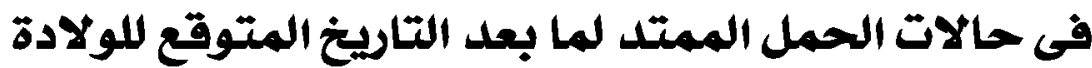

هذه الدراسة الوصفية المستقبلية على . ـا سيدة حامل تقوم بالمتابعة فى العيادات الخارجية وإستقبال الطوارئ بمستشفى آحمد ماهر

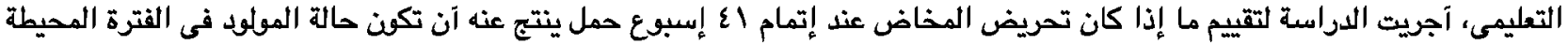

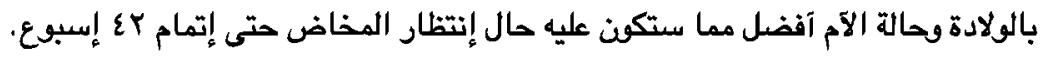

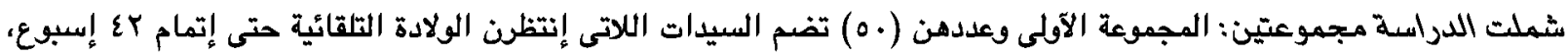

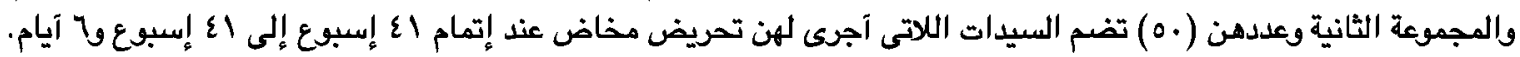

بعد الحصول على الموافقة المستنيرة من الحالات تم آخذ التاريخ المرضى الحالات وإجراء الفحوصات اللازمة لكل حالة.

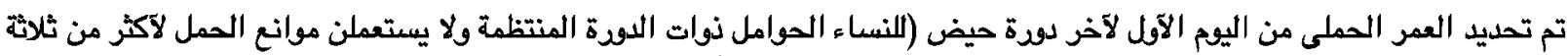

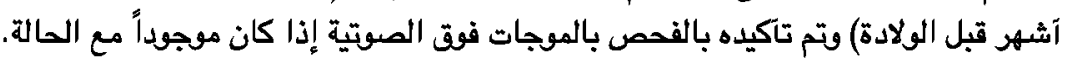

تم تقييم عنق الرحم عن طريق معادلة بيشوب المعله (على آساس إتساع عنق الرحم، وإمحاء عنق الرحم، والإتساق، والوضع والدموج). تم عمل موجات فوق صوتية حالية (آثناء هذه الدراسة) التحقق من وجود كمية سائل آمينوسى مناسب. تم عمل رسم نبض جنين اللتقييم والإطمئنان على حالة الجنين.

فحى المجموعة التى خضعت اللتخل، تم إختيار .0 سيدة عمر حملهن اع إسبوع آو آكثر عشوائياً وتمت إحالتهن إلى الستشفى لإجراء تصريض مخاض.

تم إجراء تحريض المخاض المجموعة التى خضعت اللتدخل بإستخدام قرص دينوبروستون مهبلى بامجم (يكرد بعد 1-1 ساعاعات إذا لم تستجب الحالة لآول جرعة والتى لا تتجاوذ امجم) تبعه آوكسيتوسين بالتنقيط الوريدى.

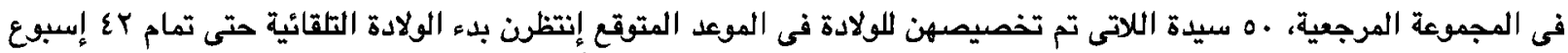

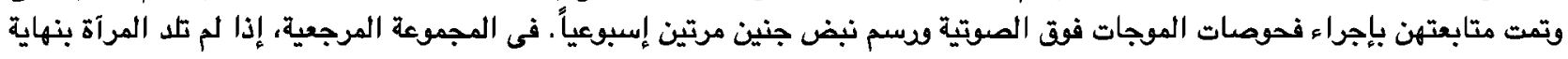

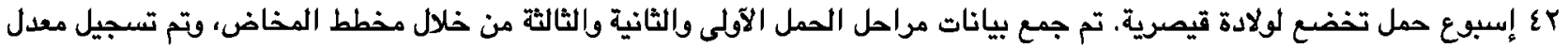

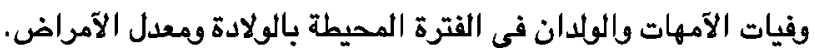

أجريت الدراسة لتقييم ما إذا كان تحريض المخاض عند إتمام إع إسبوع حمل ينتج عنه آن تكون الفترة المحيطة بالولادة آفضل مما

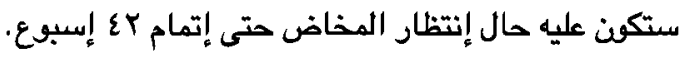

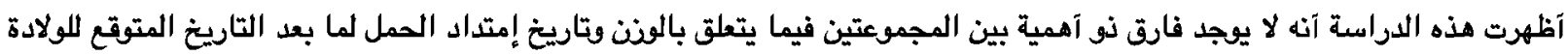

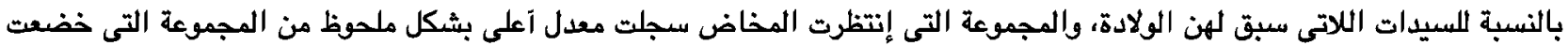
لتصريض مخاض فيما يتعلق بالعمر وعدد مرات الولادة حيث آن السيدات متعددات الولادة أكثر بكثير في المجموعة التى إنتظرت المخاض.

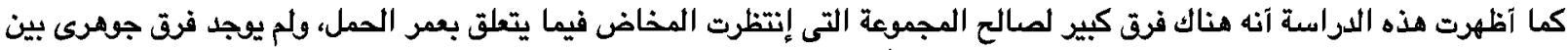

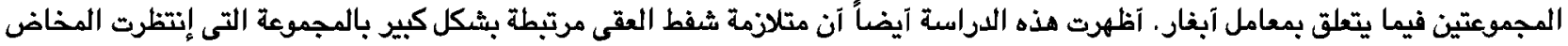

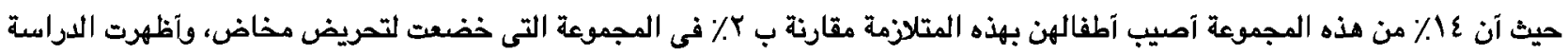

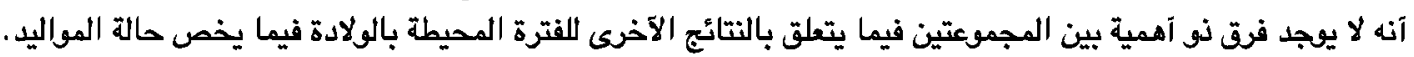

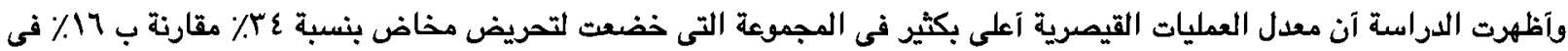

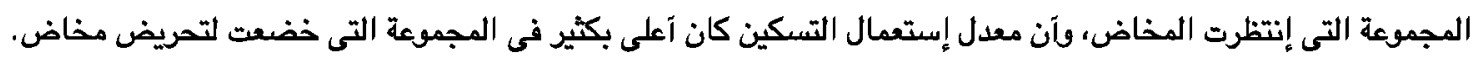

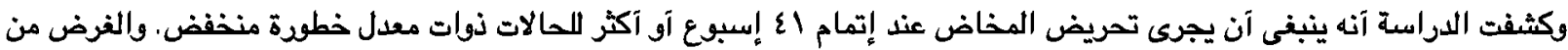

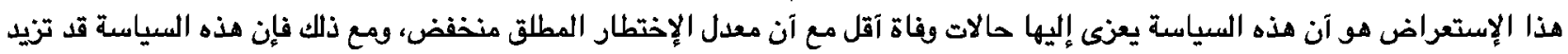
معدل العمليات القيصرية آو الحاجة إلى التسكين. 